\title{
Influence of Na Salt Solutions on the Germination, Development and Dynamics of the Activity of Nadp-Enzyme of Barley Seeds
}

\author{
B. G. Mirzoeva ${ }^{1}$
}

${ }^{1}$ Baku State University, 23 Z.Khalilov st., Baku Azerbaijan

\begin{abstract}
The influence of different concentrations of $\mathrm{NaCl}, \mathrm{Na}_{2} \mathrm{SO}_{4}, \mathrm{NaHCO}_{3}$ and $\mathrm{Na}_{2} \mathrm{CO}_{3}$ salts on the ability of growth and development of barley seeds (Hordeum vulgaris) and the influence of these concentrations on the dynamics of activity of NADP enzymes formed in plant cells such as glucose-6-phosphate dehydrogenase (G6PD, EC 1.1.1.49) anddecarboxylatingmalate dehydrogenase (MDH, EC 1.1.1.40). Solutions of Na salts had a negative effect on the growing ability and development of sprouts and the effectiveness of this effect,being directly dependent from the concentration of saline solution This action was sharply manifested at the first stages of seed germination. At the initial stages of development, the G6PD-enzyme showed great activity and the activity of the MDH-enzyme became higher in comparison with the previous one. The salt factor manifested at lower salt concentrations, led to induction of both enzymes, sproutsdevelopmen and associated compared with the previous one. The effect of salt solutions led to a decrease the activity of G6PD / MDH respectively.
\end{abstract}

Keywords: solutions of Na salts, barley sprouts, glucose-6-phosphate dehydrogenase, malate dehydrogenase.

\section{Introduction:}

Saline stress is a decisive factor in the depletion of natural resources and occupies a leading place among extreme environmental conditions. Approximately $7 \%$ of the earth's surface and $20 \%$ of the sown area are exposed to high concentrations of salts according to available data [Food and Agriculture.., 2008].

The effect of salt stress on the plant organism is complex and covers some aspects of plant metabolism. Such drawbacks as osmotic, ionic toxicity and oxidative stress at plants, which directly lead to suppression of growth and slowing development, and as a result all this affects the decrease of the productivity index [Ahmad et all., 2009; Munns et all., 2008]. The concept of the salt tolerancemechanism, the introduction of the obtained results into practical activity, the study of significant agricultural plants and the increase of their fertility is one of the main problems and immense importance for the experimenter.

Various modern methods have been used in thestudy ofthe mechanisms of plant reactions with respect to salt stress in last years, which have become a powerful tool in science. Study of genes and proteins, the study of their functions and the determination of changes in plant metabolism under stress conditions
[Yokoi et all., 2002] is one of the methods used to resolve various environmental stresses. The study of this problem havegreat importancein the production of plant varieties with high productivity in salt conditions. Plants developed a variety of protective mechanisms that they tried to use for the purpose of resistance to salt stress and to eliminate its negative influence in the evolution process. Synthesis and accumulation of osmolytes and osmoprotectors, various enzymes and non-enzymatic antioxidant synthesis can show as an example of protective reactions of some plants. Universal high-energy reducing agent is needed and would form the basis of the cellular reducing potential in order for these mechanisms to be launched by plants. NADP - such an agent acts [Drincovich et all., 2001]. Several enzymes are known that provide synthesis of NADP in a cell. Among these enzymes, the leading role belongs to glucose-6-phosphate dehydrogenase (G6PD, EC 1.1.1.49) [Wedding, 1989] and decarboxylating malate dehydrogenase (MDH, EC 1.1.1.40) [Mammadov, 2008]. Both enzymes are widely distributed in both living systems and plant objects. G6PD takes part in the cleavage of glucose in the body, namely in the pentose phosphate cycle and $\mathrm{MDH}$ is the main enzyme in malate metabolism.

This article is published under the terms of the Creative Commons Attribution License 4.0

Author(s) retain the copyright of this article. Publication rights with Alkhaer Publications.

Published at: http://www.ijsciences.com/pub/issue/2017-04/

DOI: 10.18483/ijSci.1239; Online ISSN: 2305-3925; Print ISSN: 2410-4477 
Opinion that G6PD on an equal footing with the MDH-enzyme is used to protect the formation of reactions to the effects of extreme environmental factors has been in resent years. However, role of G6PD in neutralizing of the salt stress of plant objects is not fully understood. So, we attempted to study changes in the activity of the dynamics of G6PD and MDHenzymes under the influence of different concentrations of $\mathrm{Na}$ salts.

\section{Material and Methods}

The investigations were carried out on the root system of 3, 5 and 7-day old barley sprouts (Hordeum vulgaris). Seed germination, occurrence of salt stress, receiving of G6PD [Mirzoyeva, et al., 2011] and MDH (9) enzyme preparations was carried out in accordance by the methods given earlier. Enzyme activity was determined by spectrophotometric method, at a wavelength of $340 \mathrm{~nm}$, based on the rate of reduction of NADP. The enzyme NADP was taken as the unit of activity, which for 1 minute catalyses the conversion of one micromole of substrate per minute. The accuracy index does not exceed 5\% (P $<5 \%)$.

\section{Results and discussion}

Study the different concentrations of $\mathrm{Na}$ isocathionic salts on the ability to grow barley, the dynamics of sprouts development and the study of the effect of the activity dynamics of G6PD and MDH enzymes on the root system of sprouts under the influence of stress were the main goal of researche.

Data about the effect of different concentrations of $\mathrm{NaCI}, \mathrm{Na}_{2} \mathrm{SO}_{4}, \mathrm{NaHCO}_{3}$ and $\mathrm{Na}_{2} \mathrm{CO}_{3}$ salts on the growth capacity of barley seeds have been shown in Table 1. Barley seeds soaked in distilled water amounted to $96 \%$ as shown from the table. An increase of the $\mathrm{NaCl}$ concentration to $25 \mathrm{mM}$ inthe medium had virtually no effect on the germination percentage, but an increase concentration in twice $(50 \mathrm{mM})$ resulted in an overwhelming effect and the percentage of germination decreased from 96\% to $88 \%$. More negative effect was observed at subsequent concentrations of solutions of $\mathrm{NaCI}$ salts and at a concentration of $100 \mathrm{mM}$ reached its maximum value. For example, at $75 \mathrm{mM}$ concentration of $\mathrm{NaCl}$ the germination rate was $82 \%$, and at $100 \mathrm{mMconcentration} \mathrm{-} 75 \%$.

Table 1: The effect of various concentrations of $\mathrm{NaCI}, \mathrm{Na}_{2} \mathrm{SO}_{4}, \mathrm{NaHCO}_{3}$ and $\mathrm{Na}_{2} \mathrm{CO}_{3}$ on the percentage of germination of barley seeds

\begin{tabular}{|l|l|l|l|l|}
\hline \multirow{3}{*}{$\begin{array}{c}\text { Salt concentration } \\
(\mathbf{m M})\end{array}$} & \multicolumn{5}{|c|}{ Germination (\%) } \\
\cline { 2 - 5 } & $\mathbf{N a C I}$ & $\mathbf{N a}_{2} \mathbf{S O}_{\mathbf{4}}$ & $\mathbf{N a H C O}$ & $\mathbf{N a}_{\mathbf{2}} \mathbf{C O 3}$ \\
\hline 0 & 96 & 96 & 96 & 96 \\
\hline 25 & 95 & 91 & 88 & 70 \\
\hline 50 & 88 & 83 & 71 & 65 \\
\hline 75 & 82 & 72 & 63 & 61 \\
\hline 100 & 75 & 68 & 56 & \multicolumn{2}{l}{} \\
\hline
\end{tabular}

The effect of $\mathrm{Na}_{2} \mathrm{SO}_{4}$ salt compared with $\mathrm{NaCI}$ had a more negative effect on the percentage of seed germination. As for the solutions of $\mathrm{NaHCO}_{3}$ and $\mathrm{NaCO}_{3}$ salts can come to the conclusion that, firstly, practically all of them exhibit the same effect on the germination percentage, and secondly their negative effect on this process manifests itself in a more acute form compared to $\mathrm{NaCI}$ and $\mathrm{Na}_{2} \mathrm{SO}_{4}$.

On the one hand, the ability to partially maintain the germinating capacity under the influence of similar concentration of salt solutions, on the other hand, the deprivation of this property seems to be a phenomenon associated with the variety of viability of the seeds. Most likely, seeds with low viability are not able to germinate, and in accordance with this die and seeds possessing in comparison with higher viability are able to maintain this ability under stressful conditions.

Data showing the effect of $\mathrm{Na}$ isocathion salts on the root and rhizosphere of the progenies have shown in Table 2. The salts of $\mathrm{NaCI}, \mathrm{Na}_{2} \mathrm{SO}_{4}, \mathrm{NaHCO}_{3}$ and $\mathrm{Na}_{2} \mathrm{CO}_{3}$ have a negative effect depending on the salt concentration and the time of their action as shown from this table.

Elongation of incubation time and salt concentration leads to progressive inhibition of the root and rhizosphere (basal system) of barley sprouts. 
Influence of Na Salt Solutions on the Germination, Development and Dynamics of the Activity of Nadp-Enzyme of Barley Seeds

TABLE 2

Effect of izocationic Na salt solutions on the dynamics of development of the root and rhizosphere of barley sprouts

\begin{tabular}{|c|c|c|c|c|}
\hline Indicators & $\mathrm{NaCI}(\mathrm{mM})$ & 3-day & 5-day & 7-day \\
\hline $\begin{array}{l}\text { Root size } \\
\quad(\mathrm{sm})\end{array}$ & $\begin{array}{l}0 \\
50 \\
75 \\
100\end{array}$ & $\begin{array}{l}3.6 \\
2.9 \\
2.5 \\
1.2\end{array}$ & $\begin{array}{l}7.9 \\
7.4 \\
6.9 \\
4.3\end{array}$ & $\begin{array}{l}11.4 \\
9.6 \\
8.9 \\
5.5\end{array}$ \\
\hline $\begin{array}{l}\text { Rhizosphere } \\
\text { size(sm) }\end{array}$ & $\begin{array}{l}0 \\
50 \\
75 \\
100\end{array}$ & $\begin{array}{l}2.4 \\
1.7 \\
1.3 \\
0.4\end{array}$ & $\begin{array}{l}7.2 \\
5.5 \\
4.7 \\
1.9\end{array}$ & $\begin{array}{l}9.8 \\
8.6 \\
7.6 \\
6.5\end{array}$ \\
\hline \multicolumn{5}{|c|}{$\mathrm{Na}_{2} \mathrm{SO}_{4}$} \\
\hline $\begin{array}{l}\text { Root size } \\
\quad(\mathrm{sm})\end{array}$ & $\begin{array}{l}50 \\
75 \\
100 \\
\end{array}$ & $\begin{array}{l}2.7 \\
1.9 \\
0.7\end{array}$ & $\begin{array}{l}6.8 \\
5.2 \\
3.1\end{array}$ & $\begin{array}{l}8.1 \\
6.7 \\
4.4\end{array}$ \\
\hline $\begin{array}{l}\text { Rhizosphere size } \\
\text { (sm) }\end{array}$ & $\begin{array}{l}50 \\
75 \\
100 \\
\end{array}$ & $\begin{array}{l}1.5 \\
0.7 \\
0.3 \\
\end{array}$ & $\begin{array}{l}4.7 \\
3.9 \\
1.3\end{array}$ & $\begin{array}{l}7.5 \\
6.1 \\
4.9 \\
\end{array}$ \\
\hline \multicolumn{5}{|c|}{$\mathrm{NaHCO}_{3}$} \\
\hline $\begin{array}{l}\text { Root size } \\
\text { (sm) }\end{array}$ & $\begin{array}{l}50 \\
75 \\
100\end{array}$ & $\begin{array}{l}2.4 \\
1.3 \\
0.3\end{array}$ & $\begin{array}{l}5.2 \\
3.1 \\
0.6\end{array}$ & $\begin{array}{l}6.7 \\
5.0 \\
1.9\end{array}$ \\
\hline $\begin{array}{l}\text { Rhizosphere size } \\
\text { (sm) }\end{array}$ & $\begin{array}{l}50 \\
75 \\
100\end{array}$ & $\begin{array}{l}1.2 \\
0.6 \\
0.2\end{array}$ & $\begin{array}{l}3.5 \\
0.9 \\
0.4\end{array}$ & $\begin{array}{l}6.6 \\
4.7 \\
3.5\end{array}$ \\
\hline \multicolumn{5}{|c|}{$\mathrm{Na}_{2} \mathrm{CO}_{3}$} \\
\hline $\begin{array}{l}\text { Root size } \\
\quad(\mathrm{sm})\end{array}$ & $\begin{array}{l}50 \\
75 \\
100\end{array}$ & $\begin{array}{l}2.5 \\
1.6 \\
0.3\end{array}$ & $\begin{array}{l}5.4 \\
3.0 \\
0.5\end{array}$ & $\begin{array}{l}6.9 \\
5.3 \\
1.6\end{array}$ \\
\hline $\begin{array}{l}\text { Rhizosphere size } \\
\text { (sm) }\end{array}$ & $\begin{array}{l}50 \\
75 \\
100\end{array}$ & $\begin{array}{l}1.1 \\
0.3 \\
0.1\end{array}$ & $\begin{array}{l}3.7 \\
0.5 \\
0.2\end{array}$ & $\begin{array}{l}5.6 \\
4.5 \\
3.4\end{array}$ \\
\hline
\end{tabular}

For example, in 7-day old sprouts compared to the control variant at a $50 \mathrm{mM}$ concentration of $\mathrm{NaCI}$ the development of the root system was $84.2 \%$, at 75 $\mathrm{mM}-78.1 \%$, and at $100 \mathrm{mM}-48.2 \%$.

Saline stress, which has arisen from the side of $\mathrm{NaCI}$ salt solutions also has an inhibitory effect on the dynamics of the development of the rhizosphere (basal system) and significantly inhibits the course of this process.

Negative effect in the root system also depending from the salt concentration and its exposure time. As the concentration increases, a sharp inhibitory effect is observed on the growth rate of the aerial part of the sprouts and reaches its maximum value at $100 \mathrm{mM}$ concentration. This negative influence manifests itself in the early stages of incubation.
The nature of the effect of solutions of $\mathrm{Na}_{2} \mathrm{SO}_{4}$ salts on the dynamics of the development of the root and rhizosphere of barley sprouts also resembles the influence of $\mathrm{NaCl}$ salts. In this case, seeing with increase of the salt concentration have been observedincrease the inhibitory effect on the root and basal system of sprouts, and the influence on the growth rate appears already in the early stagesof incubation. The differences are observed between the effects of saline solutions show a greater inhibitory effect of $\mathrm{Na}_{2} \mathrm{SO}_{4}$ salts than $\mathrm{NaCl}$ salts. The characteristic pattern observed under the action of $\mathrm{NaCI}$ and $\mathrm{Na}_{2} \mathrm{SO}_{4}$ salts on the development of root and rhizosphere of sprouts and associated with the time of their action can similarly manifest themselves in the case of both $\mathrm{NaHCO} 3$ and $\mathrm{Na}_{2} \mathrm{CO}_{3}$ salts. 
However, two key points arising from the influence of these salts and associated with stress conditionsare possible to note. Firstly, the result of their influence on the course of this process is very similar, and secondly, the manifestation of negative impact factor of $\mathrm{NaCI}$ and $\mathrm{Na}_{2} \mathrm{SO}_{4}$ salts on the process of their growth at the similar concentration are relatively stronger.
Dynamics of activity of cytoplasmic enzymes G6PD and $\mathrm{MDH}$, which is manifested under the influence of different concentrations of $\mathrm{NaCI}$, $\mathrm{Na}_{2} \mathrm{SO}_{4}, \mathrm{NaHCO}_{3}$ and $\mathrm{Na}_{2} \mathrm{CO}_{3}$ salts on 3-, 5- and 7day root systems of barley sprouts and the relative ratio of these activities is givenin table 3 .

\section{TABLE3}

Dynamics of the activity of G6PD and MDH enzymes, manifested under the influence of $\mathrm{NaCI}_{2} \mathrm{Na}_{2} \mathrm{SO}_{4}$,

$\mathrm{NaHCO}_{3}$ and $\mathrm{Na}_{2} \mathrm{CO}_{3}$ salts on 3-, 5- and 7-day root systems of barley sprouts and these relationactivities.

\begin{tabular}{|l|l|l|l|l|l|l|l|l|l|l|}
\hline \multirow{2}{*}{ Variants } & \multicolumn{3}{|c|}{ G6PD activity } & \multicolumn{3}{c|}{ MDH avtivity } \\
\cline { 2 - 10 } & 3-day & 5 -day & 7-day & 3-day & 5 -day & 7-day & 3-day & 5-day & 7-day \\
\hline Control & 261 & 255 & 230 & 56 & 75 & 102 & 4.7 & 3.4 & 2.3 \\
\hline $\mathrm{NaCI}$ & & & & & & & & & \\
$25 \mathrm{mM}$ & 278 & 270 & 253 & 70 & 92 & 133 & 4.0 & 2.9 & 1.9 \\
$50 \mathrm{mM}$ & 305 & 311 & 250 & 73 & 108 & 142 & 4.2 & 2.9 & 1.8 \\
$75 \mathrm{mM}$ & 322 & 289 & 248 & 82 & 119 & 150 & 3.9 & 2.4 & 1.7 \\
$100 \mathrm{mM}$ & 326 & 281 & 240 & 86 & 128 & 161 & 3.8 & 2.2 & 1.5 \\
& & & & & & & & & & \\
\hline $\mathrm{Na}_{2} \mathrm{SO}_{4}$ & & & & & & & & & \\
$25 \mathrm{mM}$ & 282 & 298 & 300 & 77 & 99 & 120 & 3.7 & 3.0 & 2.5 \\
$50 \mathrm{mM}$ & 302 & 313 & 308 & 84 & 111 & 128 & 3.6 & 2.8 & 2.4 \\
$75 \mathrm{mM}$ & 310 & 311 & 298 & 93 & 117 & 129 & 3.3 & 2.7 & 2.3 \\
\hline $\mathrm{NaHCO}$ & & & & & & & & & \\
$25 \mathrm{mM}$ & 283 & 260 & 253 & 73 & 107 & 127 & 3.9 & 2.4 & 2.0 \\
$50 \mathrm{mM}$ & 311 & 265 & 255 & 75 & 110 & 136 & 4.1 & 2.4 & 1.9 \\
$75 \mathrm{mM}$ & 315 & 240 & 235 & 89 & 112 & 133 & 3.5 & 2.1 & 1.8 \\
\hline $\mathrm{Na}_{2} \mathrm{CO}$ & & & & & & & & & \\
$25 \mathrm{mM}$ & 281 & 257 & 249 & 68 & 108 & 125 & 4.1 & 2.4 & 1.9 \\
$50 \mathrm{mM}$ & 291 & 248 & 237 & 76 & 112 & 121 & 3.8 & 2.2 & 2.0 \\
$75 \mathrm{mM}$ & 285 & 211 & 208 & 85 & 101 & 98 & 3.4 & 2.1 & 2.1 \\
\hline
\end{tabular}

Decrease in the activity of the G6PD enzyme is observed as the sprouts developas can seen from date. Different picture is observed for the MDH enzyme, here we can observean increase of activity.

For example, activity the enzyme G6PD is 97.7 and $88.1 \%$, respectively in the root system of 5- and 7day old sprouts compared with the root system of 3day sprouts.

As for the MDH enzyme is a reverse picture, compared with 3-day sprouts, the activity is $33.9 \%$ for 5-day sprouts and increase till $82.1 \%$ for 7 daysprouts. This, in turn, leads to significant changes in the G6PDG/MDH relations. This relation for 3day sprouts -4.7 , for 5 -days -3.4 and for 7-days 2.3.

So, $82.3 \%$ of general activity of both enzymes account for the G6PD enzyme and $17.7 \%$ for $\mathrm{MDH}$ at 3-day-old sprouts; but for 5-day sprouts $77.3 \%$ account for G6PD and $22.7 \%$ for $\mathrm{MDH}$, then for 7 - day sprouts $69.3 \%$ account for G6PD and $30.7 \%$ for $\mathrm{MDH}$. Hence, the role of the MDH enzyme increases in parallel with seeds develop.

Those, dynamics of activity of G6PD and MDH cytoplasmic enzymes depends both from the concentration of isotonic $\mathrm{Na}$ salts and from the time of their action. Reduced salt concentration $(25 \mathrm{mM})$ of NaCI promotes the induction of G6PD enzyme activity,but it has no effect on the dynamics of its activity.At certain periods under the influence of the $\mathrm{NaCI}$ salt the activity of the G6PD enzyme increases markedly in comparison with the control variant. However, in the case of the control variant, the tendency to decrease remains. Apparently, a relatively high index of enzyme activity within the seed under the influence of a low concentration of $\mathrm{NaCl}$ salt helps to eliminate those deficiencies that have arisen under the influence of this concentration.

There is mutual relationship between the concentration of salt solution, the time of its exposure and the degree of induction of enzymatic activity as 
shown form number in table. The concentration of salt and the time of exposure only within certain limits can contribute to the maximum induction of the enzyme. For example, such an effect can be observed at $50 \mathrm{mM}$ salt concentration on the effect of the root system of 5-day old sprouts. In other cases, despite the increase of concentration and time of exposure the induction effect not only does not increase proportionally, conversely begins to weaken. Such result can be associated with intracellular accumulation of salts ionsof $\mathrm{NaCl}$ and their direct action on the enzyme protein, which contributes to its denaturation (partial denaturation).

As noted earlier in the root system of sprouts the activity of the MDH enzyme increases in contrast to G6PD. The enzyme is also subjected to inductionunder the influence of solutions of $\mathrm{NaCI}$ salts. However, direct proportional relationship is observedbetween the exposure period and the induction effectwithin certain limits under used concentration unlike G6PD.

For example, different concentrations from $25 \mathrm{mM}$ to $100 \mathrm{mMof} \mathrm{NaCl}$ salt promote a gradual increase of activity and reach their maximum value. At this stage, compared to the control, the increase - $53.6 \%$. For 5 day-old sprouts this indicator is $70.7 \%$, for 7 day-old sprouts $-57.8 \%$, respectively.In the process of comparing the manifestations of induction of G6PD and MDH enzymes can come to the conclusion that, $\mathrm{NaCl}$ salt in comparison with the controleis a stronger induction effect on the $\mathrm{MDH}$ enzyme compared to G6PD. This in turn affects the relation of the activities of G6PD / MDH enzymes.

Thus, in the control variant for 7-day old sprouts this relation is 2.3 , in the variant at $25 \mathrm{mM}$ concentrations - 1.9 , at $50 \mathrm{mM}-1.8$, at $75 \mathrm{mM}-1.7$, at $100 \mathrm{mM}$ 1.5 , respectively. It should be noted that to a greater or lesser extent this picture refers to 3- and 5-days sprouts, respectively. At the development stage of sprouts during the incubation period an increase of the $\mathrm{NaCl}$ concentration is accompanied by a relative snapping of G6PD/MDH activity.

Development of sprouts not only promotes an increase of the activity of the MDH enzyme, but also contributes to increase in the response reaction to salt stress and increase to the role of salt adaptation conditionsallow us to conclude from the obtained results.

Relatively low concentrations of $\mathrm{Na}_{2} \mathrm{SO}_{4}(25 \mathrm{mM}$ and $50 \mathrm{mM}$ ) promote an increase of G6PD activity in the root system of sprouts and high $-75 \mathrm{mM}$ to a weak inhibitory effect. The stimulating effect of $\mathrm{Na}_{2} \mathrm{SO}_{4}$ salts on the enzymatic activity of $\mathrm{MDH}$ is somewhat different in its nature from the stimulating effect of G6PD. In this case, the effect of salt solutions depends both from the concentration and their action time. During the incubation period at 25 and $50 \mathrm{mM}$ concentrations the enzymatic activity is appreciably stimulated, at $75 \mathrm{mM}$ concentration the stimulating effect mainly encompasses 3- and 5-day old sprouts, and during the incubation process of 7days sprouts are drastically reduced.

Eeverything remains the same in the case of $\mathrm{NaCl}$.As for $\mathrm{Na}_{2} \mathrm{SO}_{4}$, depending on the degree of concentration and actiontime of the activity of G6PD/MDH comparison with the control is prone to a gradual decrease. The responsible reaction to salt stressand the increase of the role of MDH enzyme to salt adaptation associated with the development of sprouts makes.

As to the action of $\mathrm{NaHCO} 3$ and $\mathrm{Na}_{2} \mathrm{CO}_{3}$ on the root system the dynamics of the activity of cytoplasmic enzyme G6PD, apart from minor nuances, practically the same. These salts promote the stimulation of enzymatic activity. $\mathrm{NaHCO}_{3}$ salts even in to a small extent contribute to greater stimulation compared to $\mathrm{Na}_{2} \mathrm{CO}_{3}$. The stimulating effect of salts is mainly observed on the third day of incubation. In subsequent periods, a decrease in the dynamics of enzyme activity can be seen and at the $75 \mathrm{mM}$ concentration of $\mathrm{Na}_{2} \mathrm{CO}_{3}$ salt - even greater decline in comparison with the activity of the control variant. So, high concentration of salts and prolonged exposure leads to the replacement of the stimulating effect on a weak inhibitory effect. As with other variants, in the case of $\mathrm{NaHCO}_{3}$ and $\mathrm{Na}_{2} \mathrm{CO}_{3}$, the lengthening of the incubation promotes a marked decrease in the G6PDG / MDH relation, which in turn indicates the role of the $\mathrm{MDH}$ enzyme in the response to salt stress.

Thus, the activity of the G6PDH enzyme decreases in the root system of seeds and the activity of $\mathrm{MDH}-$ increases with the development of barley sprouts. Relatively soft concentrations of solutions on an equal inhibitory effect contribute to the induction of the activity of both enzymes.

\footnotetext{
References

I. Food and Agriculture Organization, 2008

II. Ahmad P., Sharma S. (2009) Salt stress and phytobiochemical responses of plants. Plant soil Environment, v. 54, pp. 89-99.

III. Munns R, Tester M. Mechanisms of salinity tolerance. Ann Rev Plant Biol, 2008, v. 59, pp. 651-681
} 
Influence of Na Salt Solutions on the Germination, Development and Dynamics of the Activity of Nadp-Enzyme of Barley Seeds

IV. Yokoi S., Bressan R., Hasegawa P. (2002) Salt Stress Tolerance of Plants. JIRCAS Working Report, pp. 2533

V. Drincovich M., Casati P., Andreo C. (2001) NADPmalic enzyme from plants: A ubiquitous enzyme involved in different metabolic pathways // FEBS Lett., v. 490, p. $1-6$

VI. Wedding R. Malic enzyme of higher plants. Characteristics, regulation and physiological function // Plant Physiol., 1989, v. 90, p. 367-371

VII. Mammadov Z.M. (2008) Physiological functions of malic enzyme in plants // Bulletin of Baku State
University, series of natural sciences, № 4, pp. 60-70 (in russian)

VIII. 8.Mirzoyeva B.G., Mammadov Z.M. (2011) Effect of salt stress on the activity of the enzyme glucose-6phosphate dehydrogenase in the root system of barley sprouts. Proced.of Institute of Botany of ANAS, XXXI, pp. 377-380 (in russian)

IX. 9.Mirzoyeva B.G., Mammadov Z.M. (2012) Effect of salt stress on the activity of the enzyme decarboxylating malate dehydrogenase in the root system of barley sprouts. Scientific Regional Center of ANAS,Ganja, Azerbaijan, pp. 9-12 (in russian) 